\title{
Nyfødtmedisin i India
}

\author{
Ola Didrik Saugstad \\ Pediatrisk Forskningsinstitutt, Rikshospitalet, 0027 Oslo \\ Telefon: 22869110 Telefax: 22869117 E-mail: o.d.saugstad@rh.uio.no
}

ENGLISH SUMMARY

Saugstad OD. Newborn medicine in India. Nor J Epidemiol 1997; 7 (1): 99-102.

India has the largest newborn population in the world with approximately 25 million deliveries annually. Of these 1.3 million die in the newborn period and 4 million before the age of five. The last years newborn medicine has become a high priority area in India. The goals by the year 2000 are to reduce perinatal mortality from 60 to $30-35 / 1000$ and infant mortality from 74 to $<60 / 1000$. The number of low birth weigth infants is today approximately $30 \%$ and the goal is to reduce this to $10 \%$ at the turn of the century. A number of efficient strategies have been developed in order to reduce perinatal and neonatal mortality. Since 1992 the socalled Child Survival and Safe Motherhood (CSSM) program has contributed significantly to reduce mortality and improve newborn care. The Indian approach is very systematic summing up in a few key points the necessary care which should be provided at each level. Developing countries could certainly learn from the Indian experience in solving their own health problems. The strategy for improving the skills in newborn resuscitation has for instance been very successfull by implementing the program: 'Give a breath, save a life'. In the course of only 3 years more than 10000 health care workers were trained in resuscitation procedures.

\section{INTRODUKSJON}

Av de omtrent 140 millioner barn som fødes i verden hvert år blir 25 millioner født i India og i år 2000 regner man med at det vil bli født over 30 millioner barn i dette landet $(1,2)$. Det er derfor ikke noe annet land i verden som har ansvaret for flere nyfødte enn nettopp India. Av disse 25 millionene dør 1,3 millioner i nyfødtperioden - før de er fylt 4 uker - og 4 millioner før de er fem år. Den indiske regjeringen har prioritert nyfødt- og spedbarnsmedisin de siste årene blant annet ut fra den erkjennelse at det høye fødselstallet ikke vil gå ned før barnedødeligheten blir redusert. I 1980årene var gjennomsnittlig familiestørrelse 4,4 barn og innen år 2000 håper man at denne er falt til 2,3. Dette mener man vil redusere fødselsraten med 50\%.

\section{STATUS FOR NYFØDTE OG SPEDBARN I INDIA}

Tabell 1 viser en del nøkkeltall som relaterer seg til nyfødte og spedbarn i 1992. Norske tall er tatt med for sammenligning $(1,2)$.

Av barn med lav fødselsvekt var omtrent $1 / 3$ født for tidlig og resten hadde vært utsatt for intrauterin veksthemning. Den lavere fødselsvekten i India sammenlignet med Norge skyldes altså sansynligvis ikke genetiske forskjeller, men reflekterer hovedsake- lig de indiske mødrenes dårligere ernæringsstatus. Dødeligheten uansett hvilket mål man bruker, er omtrent 10 ganger høyere i India sammenlignet med Norge (tabell 1).

Av dødsfall i nyfødtperioden døde $15 \%$ i første levedøgn og halvparten i første leveuke. $80 \%$ av alle nyfødtdødsfall og $50 \%$ av alle spedbarndødsfall skjedde blant barn med lav fødselsvekt. Dødsfall blant nyfødte utgjorde mer enn $60 \%$ av alle spedbarnsdødsfallene.

Spedbarnsdødeligheten har falt fra 129 per $1000 \mathrm{i}$ 1976 til 74 per 1000 i 1992. Dette skyldes en betydelig reduksjon både i den neonatale og postneonatale dødeligheten. I motsetning til spedbarnsdødeligheten har den perinatale dødeligheten bare vist en beskjeden reduksjon på ca 7\%o fra 1981 til 1992.

Tabell 1. Nøkkeltall for nyfødte og spedbarn i India og Norge i 1992.

\begin{tabular}{lcc}
\hline & India & Norge \\
\hline Gjennomsnittlig fødselsvekt, kg & 3 & 3,6 \\
Andel med fødselvekt $<2,5 \mathrm{~kg}$ & $1 / 3$ & $1 / 20$ \\
Fødselsasfyksi & $50 / 1000$ & $2-5 / 1000$ \\
Perinatal dødelighet & $60 / 1000$ & $6 / 1000$ \\
Neonatal dødelighet & $50 / 1000$ & $4 / 1000$ \\
Spedbarndødelighet & $74 / 1000$ & $6 / 1000$ \\
\hline
\end{tabular}


De fleste fødsler i India er hjemmefødsler og skjer i landsbyen. De tradisjonelle fødselshjelperne, TBA (Traditonal birth attendants), eller Dais, er de som assisterer kvinnen ved fødselen. En Dai er en ufaglært kvinne som tradisjonelt er blitt opplært av sin svigermor. De har ofte lav status i landsbyen. Mange av dem er gamle, og de kan verken lese eller skrive. Siden de ofte ikke kan telle til mer enn 8-10 kan de ikke telle pulsen. De kan ofte ikke lese av en vekt eller termometer, man bruker derfor fargekoder. Et problem er imidlertid at siden dette er eldre kvinner er synet ofte blitt så dårlig at de ikke kan lese av kodene uten briller, som de ikke har. Til tross for dette, det er disse som må danne grunnlaget for den indiske fødselshjelpen.

\section{ÅRSAKER TIL DØD I NYFØDTPERIODEN}

Hvorfor er dødeligheten så høy i India? En hovedårsak er manglende eller sviktende fødselshjelp. I 1990 var $56 \%$ av alle fødsler uten en trenet person tilstede, og bare $23 \%$ skjedde på institusjon. Det er viktig i denne sammenhengen å understreke at India er et kontinent med store regionale forskjeller. I staten Kerala i sør, som har den laveste dødeligheten, er nyfødtdødeligheten bare 11/1000 mens den er 73/1000 i staten Orissa i øst. I Kerala skjer $90 \%$ av alle fødsler på institusjon, mens for eksempel i statene Rajastan og Uttar Pradesh skjer dette i færre enn 5\%.

De viktigste årsakene til neonatal død kan tilbakeføres til tre hovedkategorier; 1) prematuritet/lav fødselsvekt, 2) fødselsasfyksi/fødselsskader, 3) infeksjoner (sepsis, pneumoni og diare). For 15 år siden døde 0,35 millioner nyfødte av tetanus - mellom $1 / 4$ og $1 / 3$ av alle nyfødtdødsfall. Ved en effektiv vaksinasjonskampanje er denne dødsårsaken nå nærmest blitt utryddet de siste årene. Dette er den viktigste årsaken til reduksjonen i neonataldødelighet i denne perioden.

\section{MÅLSETNINGER OG STRATEGIER FOR Å REDUSERE DØDELIGHETEN}

Den indiske målsetningen innen år 2000 er å redusere den perinatale dødelighet til 30-35/1000 og spedbarnsdødeligheten til <60/1000. 1-5 års mortaliteten ønsker man å senke fra 15-20/1000 til 10/1000. Antall barn med lav fødselsvekt tar man sikte på å få redusert til < 10\%. Også mødredødeligheten er høy, 2-3/1000, og man tar sikte på å redusere denne til < 1/1000.

Den indiske regjeringen har siden 1992 integrert mødre og barnehelse i et program, Child Survival and Safe Motherhood Program (CSSM). Dette programmet tar sikte på å bygge opp en basal nyfødtomsorg, vaksinasjoner, adekvat behandling av diare og gi vitamin A profylakse til barn. Tilbudet til den gravide kvinnen kan oppsummeres i 10 punkter (Tabell 2) og til nyfødte i 5 punkter (Tabell 3).

I 1997 tar man derfor sikte på å trene opp 600000 TBA, for å sikre at i hvert fall en TBA i hver landsby har opplæring til å iversette punktene i tabell 1 og 2 .
Tabell 2. Tilbud til den gravide kvinnen for å redusere nyfødtdødeligheten.

1. Tidlig registrering av svangerskapet

2. Tre antenatale kontroller

3. Tetanusvaksine

4. Jern-folsyre tabletter

5. Rådgiving om ernæring og hvile

6. Identifisering og henvisning av risikofødsler

7. Fødsler under oppsyn av trenet personale

8. Risikofødsler på institusjon

9. Adekvat behandling av obstetrisiske akuttsituasjoner

10. Rimelig intervall mellom fødselene

Tabell 3. Fem punkter for å bedre nyfødtomsorgen i India.

1. Adekvat gjenoppliving etter fødselsasfyksi
2. Forebyggelse av hypothermi
3. Forebyggelse av infeksjoner
4. Amming
5. Henvisning av syke nyfødte til kompetansesentra

Også legene har fått opplæring i nyfødtomsorg. CSSM programmet har også som oppgave å skaffe til veie nødvendig utstyr for å ta hånd om nyfødte på alle nivåer av helsesystemet.

Syke nyfødte blir klassifisert i tre kategorier; mild, alvorlig, og svært alvorlig sykdom. Eksempel på mild sykdom er væsking fra navlen, konjunktivitt, hudinfeksjoner, og trøske. Tegn på alvorlig sykdom er diare, rask pust, dårlig matlyst og sugeevne, minsket aktivitet, og feber. Symptomer og tegn på meget alvorlig sykdom er summert opp i 10 punkter: spisevegring, cyanose, hypotermi, utvidet mage, pustestopp, kramper, gryntende respirasjon, blødning, ikke-fysiologisk gulsott og fødselsvekt $<1500$ gram. Mild sykdom behandles hjemme, alvorlig sykdom ved helseinstitusjon og meget alvorlig sykdom ved sykehus med spesialister.

Nyfødtmedisinen er den best utviklete subspesialitet $\mathrm{i}$ indisk pediatri. Nyfødtavdelingene deles gjerne inn i 3 nivåer. På nivå II skal man minimum kunne ta hånd om 300 risikobarn årlig, og ha i hvert fall 10 neonatale intensivsenger. Det skal være minimum 1500-2000 fødsler årlig ved et slikt senter. I dag er det mer enn 30 avdelinger som oppfyller kravene til å bli klassifisert som en såkalt nivå II enhet, mens ingen er ennå kvalifiserte til såkalt nivå III enhet. Omtrent 30 sentra driver respiratorbehandling av nyfødte, mens bare 10 har full kompetanse for å drive neonatal intensivmedisin.

\section{GJENOPPLIVING AV NYFØDTE}

I 1990 ble det startet et eget gjenopplivingsprogram for nyfødte med tittelen: "Give a breath, save a life!" Det begynte med at 27 nyfødtleger skolerte seg og underviste andre. Man trente så opp en kjerne på 142 personer som reiste rundt og holdt seminarer. I løpet 

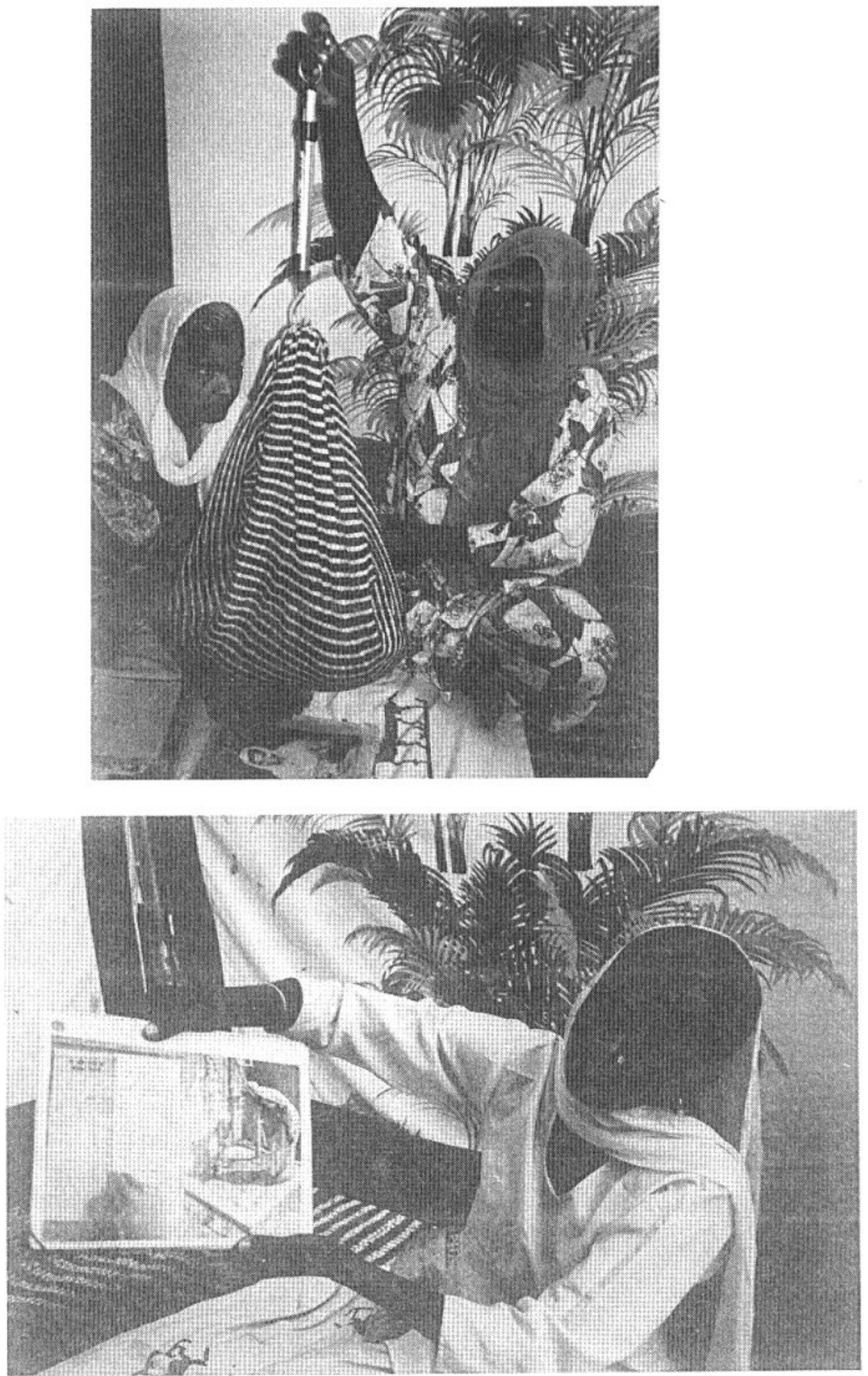

Tradisjonelle fødselshjelpere (Dais, traditional birth attendants) 
av de første tre årene holdt man 233 workshops med deltakelse av 10080 helsearbeidere, inkludert 4079 barneleger, 1848 fødselsleger eller anestesileger, 2072 sykepleiere, 1326 almenpraktiserende leger, og 775 fra andre kategorier.

\section{PRIORITERINGER I INDISK NYFØDTMEDISIN}

For det første ønsker man at fremskrittene i nyfødtomsorgen som CSSM programmet har ført med seg blir mer tilgjenglig. Man ønsker å trene opp helsearbeidere på lokalplanet $\mathrm{i}$ å identifisere symptomer og tegn som krever henvisning til sentra med høyere kompetanse. Man ønsker å bygge ut flere nivå II nyfødtavdelinger, og trene opp flere sykepleiere til å pleie nyfødte. Men først og fremst ønsker man å lære opp moren og den nærmeste familien til både å ta hånd om friske nyfødte og å identifisere tidlige tegn på sykdom.

\section{EGNE FORSKNINGSPROSJEKTER}

Siden slutten av 1980-årene har jeg hatt forskningssamarbeid med indiske nyfødtavdelinger vedrørende gjenoppliving av nyfødte. I den første studien som vi publiserte i 1993 viste vi i en pilotstudie på 84 barn at gjenoppliving med romluft kan utføres like effektivt som med $100 \%$ oksygen (3). En ny studie er nå i ferd med å avsluttes med deltakelse av 11 avdelinger i seks land. Fire av disse kommer fra India: New Dehli, Chandigar, Madras og Bombay. Studien bekrefter at romluft er meget effektivt for gjenoppliving av nyfødte og resultatene kan få stor betydning for behandlingen av nyfødte spesielt i utviklingsland.

\section{KONKLUSJON}

Nyfødtomsorgen i India står overfor store utfordringer, med dødelighetstall som er i størrelsesorden 10 ganger høyere enn i Norge. Siden India er det landet i verden som har flest nyfødte, er det selvfølgelig i global sammenheng av stor betydning hva som skjer i dette landet. Ved å besøke flere indiske nyfødtavdelinger har jeg selv sett den fremgangen som foreligger i løpet av noen få år. I vår del av verden kan vi lære av indernes måte å systematisere sykdomstegn og symptomer for raskt og effektivt å kunne henvise dem som trenger det mest til sentra med nødvendig kompetanse.

\section{LITTERATUR}

1. Paul VK. Newborn care in India: A perspective. Regional Health Forum 1996; 1: 25-31.

2. Saugstad OD. Trekk fra nyfødtmedisinen i India. Tidsskr Nor Laegeforen 1994; 114: 2015-2017.

3. Ramji S, Ahuja S, Thirupuram S, Rootwelt T, Rooth G, Saugstad OD. Resuscitation of asphyxic newborn infants with room air or 100\% oxygen. Pediatr Res 1993; 34: 809-812. 